\title{
新たな発想でのオーラルエンジニアの育成
}

\author{
田地 豪，二川 浩樹
}

\section{A novel strategies for the education of oral engineers}

\author{
Tsuyoshi Taji, DDS, PhD and Hiroki Nikawa, DDS, PhD
}

\begin{abstract}
抄 録
平成 17 年，わが国で初めて広島大学歯学部に 4 年制の歯科技工士養成機関である口腔保健学科口腔保健 工学専攻が設置された。歯科技工士をオーラルエンジニアと捉え, 新しいオーラルエンジニアには工学的 知識・技能のほかに, 生物学的知識・技能, 高度専門医療やチーム医療などに関する能力が必要になると考え, 教育カリキュラムを策定した。教養教育の充実, 材料や機器の革新に伴う専門教育の強化, 関連分野の教 育の実践を目指し，特色ある授業科目を設定している。これまでの教育の結果，卒業生は多方面で活躍し ており，今後とも，口腔工学として専門分野や関連分野で活躍できる人材の育成に努めていきたいと考え ている.
\end{abstract}

和文キーワード

4 年制歯科技工士教育，バイオデンタル教育，Interprofessional education (IPE)，再生医療，細胞培養

\section{I 。はじめに}

現在，わが国には歯科技工士養成機関が 53 校あり， 4 年制大学, 3 年制および 2 年制の専修学校・短期大 学が存在している。このうち 4 年制大学は, 東京医科 歯科大学と広島大学の 2 校である。平成 17 年, 広島 大学歯学部にわが国で初めての 4 年制歯科技工士養成 機関である口腔保健学科口腔保健工学専攻が設置され た。本稿では，広島大学での 4 年制大学としての歯科 技工士教育の特徵と今後の歯科技工の展開について述 べてみたい.

\section{II. 広島大学歯学部口腔健康科学科の沿革}

昭和 40 年に全国 3 番目の国立大学歯学部として, 広島大学 (同時に東北大学, 新潟大学) に歯学部が設 置された。その後, 昭和 47 年に附属歯科技工士学校, 昭和 51 年に附属歯科衛生士学校が併設された。これ らの専門学校を基盤として, 平成 17 年 4 月, 口腔保
健学科口腔保健工学専攻が設置され, 口腔保健衛生学 専攻は, 前年度設置された東京医科歯科大学, 新潟大 学についで全国で 3 番目の設置となり, 口腔保健工学 専攻は, 歯科技工士教育施設として全国で初めての設 置であった。

平成 21 年 4 月には, 大学院口腔健康科学専攻（修 士課程）を設置したが，この時に学年進行の終了した 口腔保健学科を大学院の専攻名称と合わせた形で口腔 健康科学科への名称変更を行った。 また, 大学院の設 置および学科名の変更に伴い, 専攻名を口腔保健工学 専攻から口腔工学専攻にし，人材育成像として従来の 歯科技工士ではなくオーラルエンジニアの育成を行う という教育上の特色を明確化した。同年 4 月には，学 部教育として文部科学省 GP にバイオデンタル教育プ ログラムが採択され, 次世代型歯科医療を打ち出すと ともに, 歯科医師・歯科衛生士・歯科技工士融合型教育, Interprofessional Education をスタートさせた。平成 23 年 4 月, 大学院口腔健康科学専攻（博士課程後期） を設置し, 口腔工学という学術分野の構築のために教 育者・研究者の養成を目指す体制ができあがった。 


\section{生体工学, 生体材料学, 情報処理学等に関する Evidenceに基づいた最新の教育を実施して，そ の知識と技術を歯科領域の高度先進医療に活 用するとともに，医科領域にも活用できる顎口腔 医療技術者, 顎顔面補緅専門技術者 (メディカル アーティスト)並びに教育者·研究者を養成する. また, 他の医療専門職とのチーム医療に参加で きる十分な基礎的, 臨床的な医学・歯学知識お よび技術を習得した思考能力, 問題解決能力並 びに指導能力を兼ね備えた人材を養成する.}

図 1 Educational ideals of the course for oral health engineering

口腔保健工学専攻の教育理念

\section{4 年制教育への移行}

口腔保健学科の設置とそれに伴う教育カリキュラム の作成にあたり，4 年制大学設置のニーズや導入を希 望する教育科目についてのアンケート調査を行い ${ }^{1)}$, この結果も参考にした上で教育理念（図 1）と人材養 成の目標を作成した ${ }^{2)}$ 。また，4 年制教育へ移行した年 に, 移行前 5 年間と移行後での受験者・入学者の変化 を調査したところ，志願倍率，男女比，平均年齢など において変化が認められた ${ }^{3)}$.

\section{IV. 教育カリキュラム}

今から約 10 年前の学科設置当時, 口腔保健工学専 攻のカリキュラムを作成するにあたり，以下の観点か ら将来の歯科技工士像を考えてみた。歯科医療では, いわゆる差し歯，入れ歯やブリッジという昔ながらの 技工主体の治療に加えて，1990 年代後半からの接着 歯学などのような材料の研究・進歩に基づく MI を中 心とした歯科医療へと変化し，さらにインプラント治 療も一般化し, 生物学主体の歯科医療に変化していた。 当時はiPS 細胞などの発見はなかったが，研究室レべ ルでは分子生物学を基盤として, ES 細胞などの肧性幹 細胞や間葉系幹細胞などの体性幹細胞を用いた再生医 療の黎明期であり，歯槽骨の再生はすでに臨床応用さ れつつあった，研究室レベルでの歯の再生は，既に現 実化されており，80 年代には夢とされてきたような再 生した組織を用いた歯科医療が，研究の技術革新によ りあと 10 〜 20 年すれば現実化されると感じていた。 そのような中，将来，再生医療を担っていける歯科技

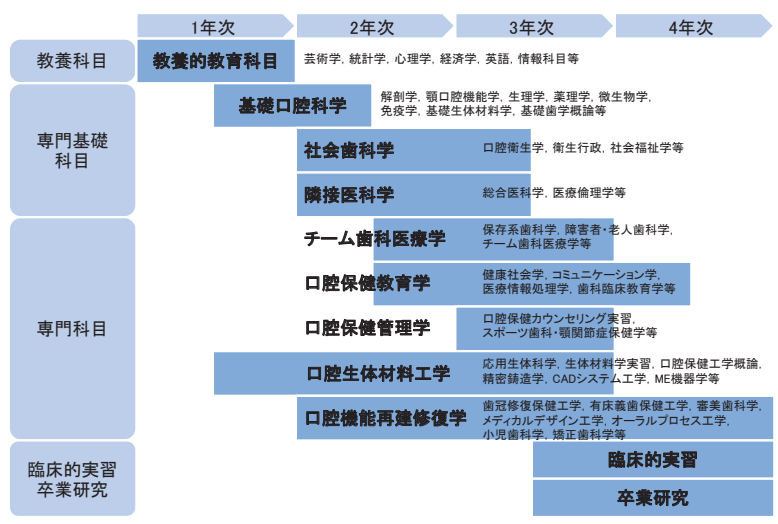

図 2 Educational curriculum of the course for oral health engineering

口腔保健工学専攻の教育カリキュラムの概要

工士の育成，あるいは工学的な知識を基に技工物や培 養システム，生体デー夕をもとに生体組織をデザイン していける人材を育成したいと考えた。例えば，歯や 骨になる幹細胞を歯科医師が採取し，細胞を歯科技工 部門で培養・分化させ，その組織を歯科医師が埋入・ 治療を行うようになればと思っていた。

このような観点から，新しいオーラルエンジニアに は工学的知識・技能の他に，生物学的知識・技能，高 度専門医療やチーム医療などに関する能力が必要にな ると考えられた。そして，これらのことを踏まえ教育 カリキュラムを検討した。図 2 にカリキュラムの概要 を示す。教養科目は主に東広島キャンパスで開講され, 本専攻の学生は他学部の学生と一緒に授業を受ける. また，専門科目は霞キャンパスで開講され，本専攻の 学生は歯学部歯学科や口腔保健衛生学専攻の学生とと もに，高度専門的で最先端の授業を受ける．本専攻の カリキュラムは，以下の点において特徵的と言える.

(1)教養科目の充実，情報処理系科目の充実

(2)隣接医学・歯科医療倫理学の教育，工学部との連携 教育

(3)社会歯科学系科目の大幅な追加・充実

(4)専門科目の体系化と充実（材料学系科目，CAD シス テム工学, ME 機器学, メディカルデザイン工学, オー ラルプロセス工学, 臨床的実習の新設・充実), 卒 業研究の充実

\section{$\mathrm{V}$ ．特色ある授業科目}

4 年制大学教育を行うことは，すなわち学士という 学位を授与するにふさわしい人間を育てることとも言 える。したがって，専門領域での技能のみならず，人 


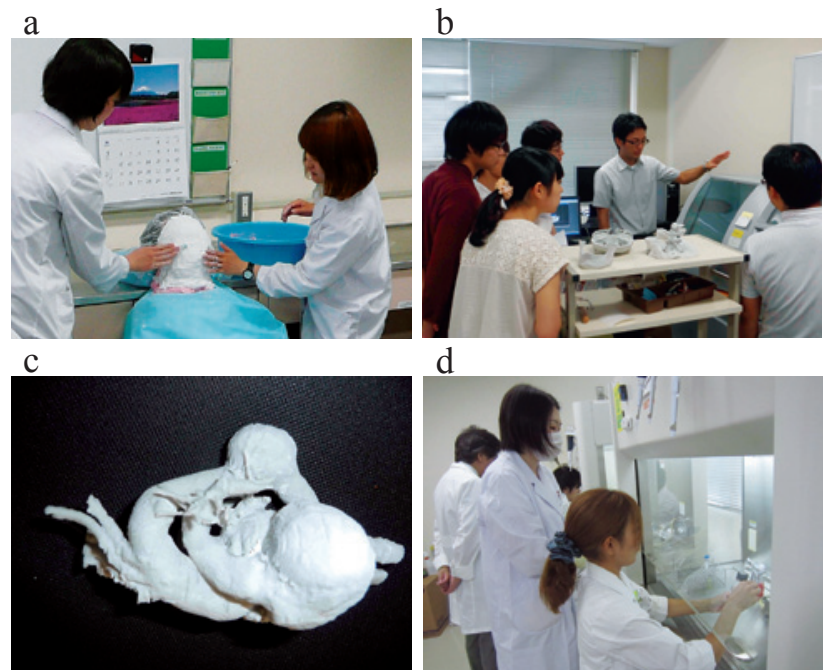

図 3 Characteristic classes a. Practice of anaplastology, b. Practice of biodental education, c. Support model for operation (Aortic aneurysm), d. Practice of tissue culturing 特色ある授業

a. アナプラストロジー実習，b. バイオデンタル教 育, c. 手術支援模型 (大動脈瘤)，d. 組織培養実習

間性，社会性，倫理性を備えたオーラルエンジニアを 養成する必要がある。そのためには，最新機器や材料 の革新に伴う先端技術教育も含めた専門教育の強化と ともに教養教育の充実が望まれる ${ }^{4,5)}$ 。ここでは，本専 攻における特色ある授業科目を紹介する（図 3 ).

\section{1. 教養科目}

医療人としての人間性を涵養する教育を進めていく には，一般教養はもちろんのこと，医療人としての自 覚や他職種とのコミュニケーションなどの教育も必要 である． 1 年前期に開講する「教養ゼミ」では，歯学 部 1 年生 93 名（歯学科 53 名, 口腔健康科学科 40 名) を 2 学科混成の 13 グループに分け, 課題を通して PBL チュートリアル教育を実施している。課題として は，社会的事項から医療に関するものまで多岐にわた り, 大学生活, 学生憲章, キャリアパス, プロフェッショ ナリズム，医療連携などを取り上げてきている，学生 は, この授業を受けることにより, 問題解決能力や自 己主導型学習能力を身につけるとともに，学科を越え た横断的な教育を行うことにより，他学科の学生との コミュニケーション能力も培われる。ささらに，グルー プ討論や成果発表会で発言・発表することで, プレゼ ンテーション能力も鍛えられる。この取り組みは，経 済産業省が提唱している社会人基礎力の育成 ${ }^{6)}$ に大 きく関与するものと考えてよいのではないだろうか.

\section{2. 専門科目}

1) $\mathrm{CAD}$ システム工学, ME 機器学, 医療システム 工学

従来から技工物製作法の理論と技術を教育している が，近年，生体情報のデジタル化や計測・加工技術の 進歩, 生体適合性材料の開発などに伴い，歯科の分野 でも $\mathrm{CAD} / \mathrm{CAM}$ が導入されてきた。 1 年後期に開講す る「CAD システム工学」, 2 年後期の「ME 機器学」, 3 年前期の「医療システム工学」などの授業を通して, 生体医工学の基礎理論, 3 次元形状計測や $\mathrm{CAD} / \mathrm{CAM}$ の原理, 歯科用 $\mathrm{CAD} / \mathrm{CAM} も$ 含めた最新の $\mathrm{ME}$ 機器 について教育している。 さらに, 学生が 3 年生まで に学んだ理論と技術は，4 年生の「臨床的実習」にお いて手術支援模型製作などの形で生かされている。ま た, CAD/CAM 冠が保険収載されたこともあり, 今後, $\mathrm{CAD} / \mathrm{CAM}$ 機器の需要の増加が予想される。これに伴 い, 機器の操作を任される歯科技工士には, 歯冠形態 をはじめ修復材料特性や機器に関する知識と技能が求 められることになり, この分野の学問がますます重要 視されることになるであろう。

2）アナプラストロジー実習

3 年前期には「アナプラストロジー実習」の授業が あり，眼窩エピテーゼと指部プロテーゼを製作してい る。使用する材料がレジンとシリコーンで異なるもの の，エピテーゼの製作過程は義歯のそれと近似してい るため，この分野は歯科技工士の活躍の場の一つであ る. 現在, エピテーゼの製作に特別な資格は必要とさ れていない.このような現状の中で歯科技工士がこの 職に就けば，国家資格を持つ者が製作した物を患者に 提供することになり, 術者・患者双方の信頼関係構築 に繋がると考えられる。

3）リハビリメイク実習

2 年前期には「口腔工学概論」の授業でリハビリメ イクの講義を，2 年の夏季休㗇には「夏期特別実習」 をそれぞれ開講しており, リハビリメイクの理論と実 践を学んでいる。 また, 実習を通じて外観・メイクが 心に及ぼす影響を考えさせている。この実習を通して， 患者の QOLを向上させるためには，これまでの人工 物を製作するばかりでなく，いろいろなアプローチが あることを，学生は理解することになる。

4) バイオデンタル教育

平成 23 年に歯学部全員参加の「バイオデンタル教育」 が開始された。図 4 にその概念を示す。このプログラ ムは, スタートアップコースワーク，専門コースワー ク，実践専門英語演習から構成されている。 スタート アップコースでは歯学科 3 年生と口腔健康科学科 2 年 


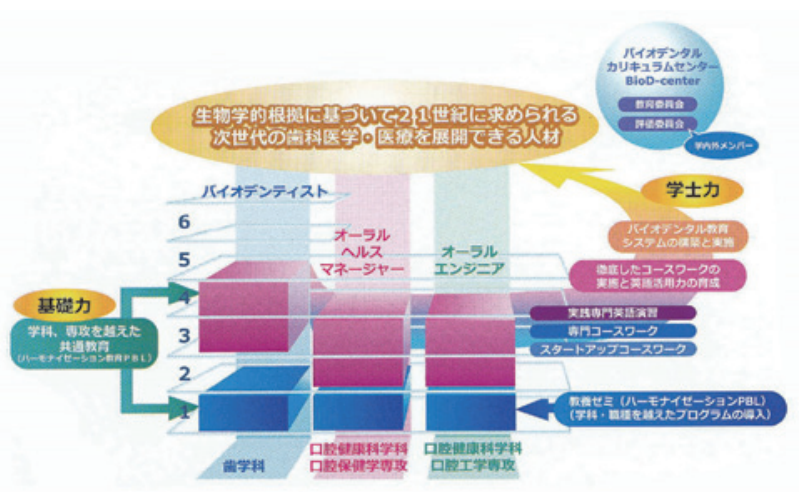

図 4 Concept of the biodental education バイオデンタル教育の概念 ${ }^{7)}$

生の混成グループを形成し，選択制で「細胞培養基礎 実習」に参加することもできる，本実習では，細胞培 養の歴史や今後の展望をはじめ, 細胞培養を行うにあ たり必要となる基本的技術を学ぶ。また，専門コース ワークでは「口腔感染学」,「診断歯学」,「再生歯学」,「口 腔機能評価学」の 4 コースを用意しており，歯学科 4 年生と口腔健康科学科 3 年生の混成 15 グループが各 コースに分かれ，生命科学に関する最新の知見や，基 礎医学研究と歯学臨床との関連性を, 実際に研究室で 実験を行いながら体験する。さらに，実践専門英語演 習は基礎英語力をもとに 10 クラスに分けられ，専門 講師による日常英会話指導から医療英語, 英語プレゼ ンテーション法や英語論文作成法などの基礎英語力を 培う。このプログラムのポイントは，(1)生物学的エビ デンスの基礎に立脚した歯科医療人を育てる。(2)学部 時代から歯科医師，歯科衛生士，歯科技工士が一体と なってともに学びあう雾囲気を作る。(3国際化に対応 できる人材を作る。の 3 点であり, 将来のチーム医療 に対応した人材作りに貢献している77.

5）組織培養実習と遺伝子組換え講習会

バイオデンタル教育とは別に, iPS 細胞の発見をきっ かけとして，卒業研究などで iPS の樹立もできるよう にと 2 年生に対して遺伝子講習会を行っている。 また, 3 年生では日本組織培養学会の細胞培養基盤技術コー ス I を開催している. 3 年生で行う組織培養実習は, ある意味きっかけであり, その後の卒業研究や修士課 程での研究で細胞を用いた研究を行い，コース II，コー ス IIIの受講後に細胞培養士の最終試験を受ける学生が いてくれればという思いであった。 日本組織培養学会 の細胞培養士の資格認定を受けたものは，全国で十数 名であるが，そのうちの4名が口腔工学出身者である. 昨年には, 日本再生医療学会も細胞培養のクオリティ を担保するために，細胞培養に対しての資格認定を行
う旨を発表しているが，実質の実習は行われておらず， 資格認定制度をスタートさせた際には，日本組織培養 学会の細胞培養士の資格認定があれば，実技免除とな るコンセンサスが得られている。

3. 臨床的実習, 卒業研究

1) 予備実習, 臨床的実習

3 年後期になると, 「予備実習」を週 1 日の割合で行 い，臨床的実習の準備を始める。ここでは，学生が診 療見学をすることで, 診療過程やその内容, 患者や歯 科医療従事者の動線, 診療室と技工室との関わりなど の理解を深めている。 さらに，4年前期から 8 力月間 （4月～11月）は「臨床的実習」を行っている.ここ では，約 20 名の学生を 8 グループに分け，病院の理 解・協力のもと，診療科をローテイトしながら臨床模 型による装置の製作や診療見学を行う。従来の技工物 に加えて手術支援模型なども製作しており，模型実習 で養った知識と技能を実際の現場で発揮している。渡 辺らは，今後の歯科技工実習 (臨床実習) では, 臨床 模型による実習, 臨床（診療）見学が不可欠であり, 実習時間を十分に確保する必要性があると報告してい る る, $^{8}$ われわれの専攻においては，4年制カリキュラ ムであることやキャンパス内に病院があることなどか ら,「臨床的実習」に十分な時間と実習環境が確保さ れているものと考えられる.

臨床実習当初から, 患者さんの CT デー夕を基に 3D プリンターで手術支援模型を製作することを行ってい るが, 現在, 口腔外科だけでなく, 歯周病治療, 歯内 療法, 矯正治療などでも応用されており, 医科とのコ ラボレーションでは, 心臓外科, 整形外科, 耳鼻咽喉 科などで活用されている。

2) コラボレーション実習

平成 24 年度から, 先端補綴学研究室と協力しながら, 歯学科の臨床実習と口腔工学専攻の臨床的実習の一部 を合同で行う「コラボレーション実習」を試行している。 ここでは, 歯学科の学生と口腔工学専攻の学生が少人 数混成グループを作り, 口腔内検査, 概形印象採得, フェ イスボウトランスファーおよび半調節性咬合器の顆路 や切歯路の調節を行っている。この実習により学生は, 顎運動, 咬合, 咬合器に関する理解はもちろんのこと, 診療室と技工室の関わりや歯科医師と歯科技工士の連 携についての理解も深めている.

3）卒業研究

3 年後期になると「卒業研究」が本格的に始まる。 学生は, 臨床的実習以降の時間を使い研究を進めてい く.また，その成果を関連学会で発表するとともに， 4 年生の 9 月に開かれる卒業研究発表会で発表し,さ 
日大学院進学 日企業 病院 日公務員

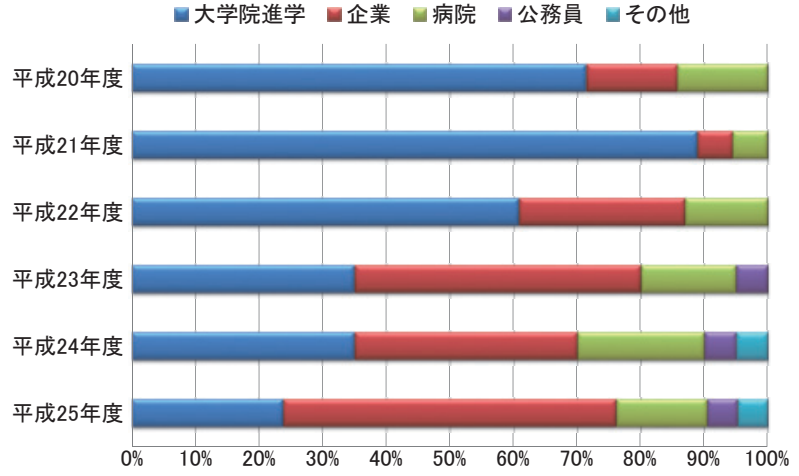

図 5 Career path of the graduates of the four-year education

4 年制に移行した後の卒業生の進路

らに 11 月までに卒業論文としてまとめている，研究 期間が 1 年間では短いと思われるかもしれないが，2 年生からのクラブ活動（バイオテクノロジークラブ, ハイパーテクノロジークラブ，アートテクノロジーク ラブ）を通じて研究の基礎を学んでおり，この段階か ら予備実験などを始めている。学生は「卒業研究」を 通して, 問題解決能力, 探求心, 考察能力, プレゼンテー ション能力，ライティング技術などを修得している.

\section{VI. 卒業後の進路}

4 年制に移行した後の卒業生の進路を図 5 に示す. 1 期生から 3 期生までは，大学院進学率が $50 \%$ を超え ていたが，最近 3 年間は，企業就職する者の割合が増 加しており，公務員になる者も出てきている．また， 病院や歯科医院に歯科技工士として就職する者の割合 は，15〜20\%である。われわれは，歯科技工士のみ ならず，教育職，研究職，営業職，医療技術職など， 幅広い将来選択の機会と環境を学生に提供している.

\section{VII. 今後の展開}

これまでの歯科技工士教育における教育内容を見直 すにあたり，課題を段階的に検討していく必要があ る ${ }^{10)}$. 現在， 53 校ある歯科技工士養成機関は，歯科技 工士学校養成所指定規則によって規定されている学科 目に基づいた教育の中で，それぞれ工夫された授業を 展開している ${ }^{11,12)}$ 。ここでは，われわれの取り組みと 今後の展開について述べる.

\section{1. 国際交流}

社会のグローバル化が進む現代，国際交流は教育に おいても必要である。われわれの歯学部歯学科では,
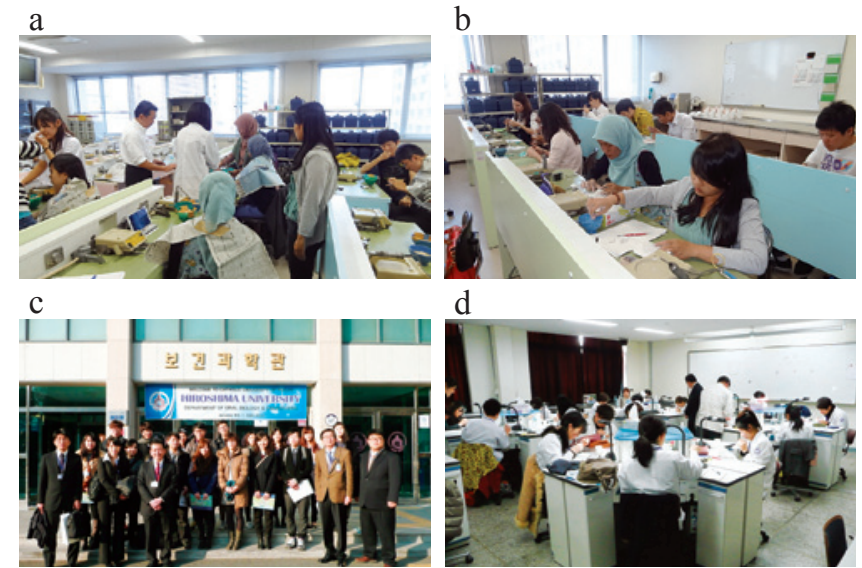

d

図 6 International exchange program

a,b. Program for the international exchange students, c. Visit to the sister school, d. Practice in the sister school

国際交流プログラム

a,b. 国際交流学生との実習，c. 協定校への訪問，

d. 協定校での合同実習

授業を日本語・英語併用の形態に変更するとともに, 新たに国際歯学コースを設置し，毎年 3 名の長期外国 人留学生を受け入れている。この他にも 6 力月短期留 学生 6 名と国際交流学生数十名をそれぞれ毎年受け入 れている。回腔工学専攻の学生は, 国際交流学生が来 学する際，一緒に実習を行いながら交流を深めている (図 6). また，カンボジアに医療支援で歯学部学生が 派遣された際には, 本専攻の学生も参加し, 海外の歯 科医療の現状を学ぶことができた。さらに，本年 1 月 には，交流協定を結んでいる韓国の大学に 8 名の学生 を派遣し, 現地の学生とともにポーセレン実習や企業 見学を行った。われわれは，現状に甘んじることなく， 学生同士の国際交流の機会を増やせるよう, 今後とも 環境の整備を進めていくつもりである.

2. Interprofessional education (IPE)

Interprofessional education（専門職種間教育，以 下 IPE）は，他職種に対するポジティブな考え方を養 うことから始まり，チームワークや協㗢スキル・能力 を習得することへ発展させることができる ${ }^{13)}$ ．われわ れの歯学部には, 歯科医師を養成する歯学科と歯科衛 生士や歯科技工士を養成する口腔健康科学科が設置さ れており，さらに，同じキャンパスに医学部や薬学部 もあるため，専門職種間教育を行いやすい環境にある. 実際， 1 年生の教養ゼミでは，PBL を歯学科と口腔健 康科学科の学生が一緒に学んでおり, バイオデンタル 教育では, 歯学科 3 年生と口腔健康科学科 2 年生がチー ムを組んで学んでいる。この他にも歯学科・ 口腔健康 


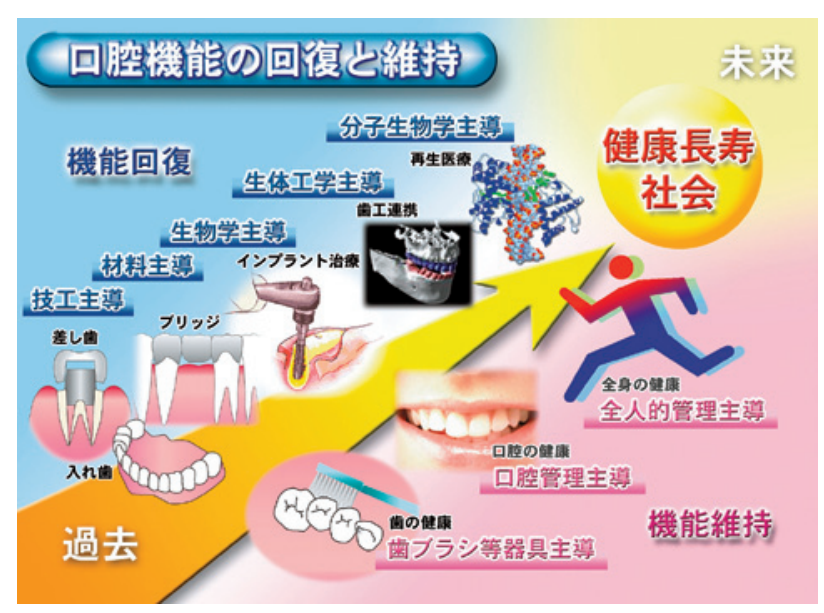

図 7 Development and future vision of dentistry 口腔機能の回復と維持における展開

科学科合同授業が多く設定されており，将来の医療現 場におけるチーム医療に対応した教育を進めていると ころである。ただし，これからのチーム医療は単に歯 科の中だけで成立するものばかりでなく，医科の他職 種との連携も必要となる。したがって，引き続きカリ キュラムに改良を加えながら，IPE のさらなる展開を 目指している.

\section{3. 口腔機能の回復における展開}

歯科技工士法において「歯科技工」とは，特定人に 対する歯科医療の用に供する補てつ物, 充てん物又は 矯正装置を作成し，修理し，又は加工することと定め られている。また，「歯科技工士」とは，厚生労働大臣 の免許を受けて歯科技工を業とする者とされている. 多少の解釈を含めて言い換えると，歯科技工士の業務 は，高度な専門的知識と技術を用いて，特定の患者に 合った精度の高い装置を製作することと言える。

ここで，われわれの考える口腔機能の回復と維持に おける展開の概念を図 7 に示す。これまでの歯科技工 は，歯科用材料や技工機器の発達，高度な技工手技な どをもってロ腔機能の回復に寄与していた．現在，デ ジタル化した生体情報を解析して高精度の装置を製作 する時代が訪れている。 また，人工物と生体の関係や 歯科治療を生物学的観点から捉えた研究が進んでい る。そして，これからの歯科技工は，再生医療にも関 わることになるであろう。これらのことを踏まえると， 今後, 歯科技工士の活躍する場はますます広がり, さ まざまなアプローチを通して患者の口腔機能の回復に 貢献するものと考えられる.

口腔健康科学科は，来年で設置 10 年を迎えるが，そ
の先新たな 10 年・20 年のためには, 各界に輩出した 卒業生の頝張りにも期待したいし，また健康長寿のた めに, あるいは介護の現場のために, 口腔工学として再 生医療後の再感染の防止や食品科学などの分野でも活 躍できる人材の育成に努めていきたいと考えている.

\section{文献}

1) 玉本光弘, 田嶋英明, 下江莘司, 村山 長, 里田隆博, 二川 浩樹, 天野秀昭。歯科関連企業を対象とした歯科技工士の需 要および教育に関するアンケート調査. 日歯技工誌 2006; $27: 43-51$.

2) 玉本光弘, 竹本俊伸. 広島大学歯学部口腔保健学科の概要 と教育カリキュラム。 日本歯技 $2006 ; 446: 33-40$.

3）下江莘司，田嶋英明，玉本光弘，里田隆博，村山 長，二 川浩樹，天野秀昭，妹尾輝明。本校におけるこれまでの歯 科技工士養成に関する分析と四年制移行による変化一学生 に関する調査一。 日歯技工誌 $2006 ； 27: 52-58$.

4）末瀬一彦。日本の歯科技工士教育の現状と展望。日歯技工 誌 $2014 ; 34: 72-76$.

5）厚生省健康政策局医事課，医療関係職種の教育課程等の改 善に関する検討会. 医療関係職種の教育課程等の改善に 関する検討会意見書一医療関係職種の質の向上を目指し て一. 1995.

6）経済産業省編。社会人基礎力育成の手引き一日本の将来を 託す若者を育てるために。東京：学校法人河合塾；2010， 2-7.

7）広島大学歯学部。広島大学歯学部 GuideBook2013 21 世 紀型歯科医療を目指して。広島 : 国立大学法人広島大学医 歯薬保健学研究院；2013, 15.

8）渡辺嘉一, 鳥山佳則, 佐藤温重, 末瀬一彦, 田上順次, 五十 嵐孝義，尾㠃順男，山㠃廣子、今後の歯科技工士の養成方 策等に関する総合的研究 (第 1 報). 日歯教誌 $2003 ; 18$ ： 387-394.

9）渡辺嘉一, 鳥山佳則, 佐藤温重, 末瀬一彦, 田上順次, 五十 嵐孝義，尾㠃順男，山㠃廣子．今後の歯科技工士の養成方 策等に関する総合的研究（第 2 報)。日歯教誌 $2003 ; 19$ ： 152-159.

10）末瀬一彦. 医療・福祉専門教育の動向 歯科技工士教育. 日本歯科医学教育学会歯科医学教育白書作成委員会編，歯 科医学教育白書 2005 年版, 東京 : 口腔保健協会 ; 2006, 164-168.

11）鈴木哲也. 東京医科歯科大学における四年制歯科技工士教 育の現状と課題. 日歯技工誌 $2013 ; 33: 61-66$.

12）野村章子。歯科医療パラダイムシフトに対応した歯科技工 士教育はどうあるべきか. 日歯技工誌 $2013 ; 33: 67-78$.

13）Dent JA, Harden RM（鈴木康之, 錦織 宏). A practical guide for medical teachers (医学教育の理論と実践。東 京：篠原出版新社；2010, 186-198. ), 2005.

著者連絡先：田地 豪

干 734-8553 広島市南区霞 1-2-3

Tel: 082-257-5622

Fax: 082-257-5797

E-mail: taji@hiroshima-u.ac.jp 